\title{
Role of Fungi in Bioremediation
}

\author{
Hussein Al Nasrawi* \\ Department of Mycologist, The Florida State university and Southern technical University, USA
}

Submission: October 02, 2018; Published: January 25, 2019

*Corresponding author: Hussein Al-Nasrawi, Department of Mycologist, The Florida State university and Southern technical University, Florida, USA

\section{Introduction}

Many chemical compounds in nature which discharged by human activities like oil spills and hydrocarbons, contain a toxic metal which consider a hazardous material against environment [1]. The nature is a huge ecological niche to fungi and bacteria which play an important role as decomposers of dead materials and converts organic matters into carbon dioxide and mineral molecules. Microorganisms have evolved a high degree of metabolic versatility that allows them to use a diverse range of organic substrates and large molecules from different complex chemicals present in nature such as hydrocarbons via activity of fungi which needs carbon source for their metabolic pathways in glycolysis process to produce primary and secondary metabolites.

The most frequently found microorganisms are bacteria and fungi, with bacteria assuming the dominant role in marine ecosystem and fungi in terrestrial environments. It has been reported that adapted communities previously exposed to hydrocarbons exhibit higher biodegradation rates than communities with no history of hydrocarbon contamination [2]. Fungi have an enormous degradative power which enable these minute living organisms to integrate human efforts and share in enhancing the nature during hydrolytic enzymes secreted by fungi into the environment contributes in digestion a large organic molecule, such as polysaccharides, proteins, lipids, and other organic substrates into smaller molecules that may then be absorbed as nutrients [3].

\section{Biodegradation Process}

Microbial degradation has emerged as the most significant natural mechanism for the removal of nonvolatile hydrocarbon pollutants from the environment and although biodegradation occurs at a distressingly slow rate, it can be enhanced by inoculation with microbial species that will degrade pollutant molecules such as oil waste more efficiently, and/or by introducing air and nutrients into the environment [4].

In biodegradation process, microorganisms consume hydrocarbons as a carbon source and microbes which can utilize hydrocarbons are found naturally in the environment; however; they grow and develop after an oil spill occurs because additional carbon source (hydrocarbons) are available following a spill [5].
Crude oil from oil spill is a naturally occurring complex mixture of hydrocarbon and non-hydrocarbon compounds which possesses a measurable toxicity towards living systems and alkanes are the most readily degraded materials, but benzene, toluene and xylene are toxic compounds [6]. Crude oils and refined fuels are very complex mixtures that vary widely depending on their source $[7,8]$. They contain thousands of molecular species, which are often grouped into four categories saturated hydrocarbons, aromatic hydrocarbons, resins and asphaltenes. The first two are amenable to gas chromatography and have been intensely studied. The last two contain heteroatoms such as oxygen, sulfur and nitrogen, and are not amenable to gas chromatography. Until recently their identity was unknown, but recent developments in high resolution mass spectrometry $[9,10]$.

The hydrocarbon-biodegrading populations are widely distributed in the world's oceans; surveys of marine bacteria indicate that hydrocarbon-degrading microorganisms are ubiquitously distributed in the marine environment which often exceed $10 \%$ of the total bacterial population. Since bacteria are the dominant hydrocarbon degraders in the marine environment, the biodegradation of aromatic hydrocarbons results in detoxification and does not produce potential carcinogens. The complete biodegradation (mineralization) of hydrocarbons produces the non-toxic end products carbon dioxide and water, as well as cell biomass (largely protein) which can be safely assimilated into the food web [11].

Using an indigenous microorganism consortium ensurethat the organisms have a higher tolerance to the toxicity of hydrocarbons and are resistant to variations in the environment [12]. More complex structures are more resistant to biodegradation, meaning that fewer microorganisms can degrade those structures and the rates of biodegradation are lower than biodegradation rates of the simpler hydrocarbon structures found in petroleum. The greater the complexity of the hydrocarbon structure, i.e., the higher the number of methyl branched substituents or condensed aromatic rings, the slower the rates of degradation [11].

Agricultural byproducts are used to transfer the microorganism consortium to the fields effectively. The carrier 
materials provides nutrients, moisture, and physical support for the increased aeration needed by the microorganisms, and also assist in extending the survival of the microorganisms until they are applied in the field [13].The effect of oil on microbial populations in the area subjected to oil spill, depends upon the chemical composition of the oil and on the species of microorganisms present, and populations of some microbes increase; typically, such microbes use the petroleum hydrocarbons as nutrients . If oil reaches a shoreline, biodegradation can be stimulated by carefully delivering biologically available nitrogen and phosphorus to at least partially reduce their limitation on microbial growth [14].

The same crude oil can favor different genera at different temperatures [15]. However, some crude oils contain volatile bacteriostatic compounds that must degrade before microbial populations can grow [11,16]. Microbial populations must begin to use oil and expand their population before measurable degradation takes place, a period usually lasting several days. This fact becomes very important when considering the appropriateness of bioremediation as a quick or first response technique [17].

Many published interested with biodegradation of oil, both in the laboratory and in field trials and a number of advanced researches were published during the 20th century, including review papers and papers presenting results from the fields which measured degradation rates in different ecosystems. [18] demonstrated that the rate of biodegradation of the three and four ring aromatic compounds in Prestige cargo oil decreased substantially after all the n-alkanes had been degraded, even in the presence of nutrients. [19] saw a similar effect in their field trial on the Delaware Bay, as did [20] in continuous flow microcosms. This may be a reflection of co-metabolism [21], or perhaps the fact that alkane degraders such as Alcanivorax grow much faster than aromatic degraders such as Cycloclasticus [22,23]. In either case, while it does not indicate that biodegradation has ceased, it does suggest that the system is unlikely to be fertilizer-limited once the alkanes are degraded. Several studies demonstrated oil spills, like the Amoco Cadiz measured oil degradation in the environment [17].

\section{Bioremediation of Polluted Environment}

The use of microorganisms, either naturally occurring or introduced, to degrade pollutants is called bioremediation. It means decomposition of hard substrate may be as a form of hazardous contaminants discharged to the environment, specially when the organisms that are native to a contaminated site effectively remove contaminants without intervention, the toxicity at the site may simply be monitored as the pollutant is reduced or converted to a less toxic form [24]. Bioremediation consider one of the important growing area of applied microbiology, it is not a new concept, microbiologists have studied the process since the 1940s. However, bioremediation became known to a broader public in the U.S. only in the late 1980s as a technology for cleanup of shorelines contaminated with spilled oil.
The Exxon Valdez oil spill in 1989 in Prince William Sound, Alaska was the catalyst for this attention. In the years since 1989, bioremediation has become a technology that is discussed, applied, and considered in many different circumstances [17]. Perhaps the most attractive feature of bioremediation is the reduced impact on the natural ecosystems, which should be more acceptable to the public [25]. A few papers discuss the potential applications for fungal bioremediation [1]. A number of bioremediating microorganisms have been isolated from contaminated sites, but it is now generally understood that the information obtained from these isolates is insufficient to understand the workings of complex microbial communities. More complete genetic information from natural environments is required to understand how contamination affects microbial communities on the whole, and whether there is the potential for further optimization of bioremediation. [24]. Although, the use of bioremediation to remove pollutants is typically less expensive than the equivalent physical-chemical methods, this technology offers the potential to treat contaminated soil and groundwater on site without the need for excavation [26], it requires little energy input and preserves the soil structure [27].

Bioremediation of oil contaminated beaches was shown to be a safe clean-up technology. The addition of fertilizers caused no eutrophication, no acute toxicity to sensitive marine test species, and did not cause the release of undegraded oil residues from the beaches [28]. Many researches have recently been demonstrated the use of biodegradation of oil spill in the polluted beaches, seawater and freshwater during isolation of many fungal isolates from polluted areas and used it in bioremediation. In marine environments contaminated with hydrocarbons, there is an increase in the proportion of bacterial populations with plasmids containing genes for hydrocarbon utilization. The proportion of hydrocarbon-degrading bacterial populations in hydrocarboncontaminated marine environments often exceed $10 \%$ of the total bacterial population [11].

Generally, the presence of hydrocarbon-degrading microorganisms is not the limiting factor in petroleum bioremediation. Hydrocarbon-oxidizing bacteria have been isolated from a wide variety of natural aquatic and terrestrial environments, including hydrothermal vent sites [29]. Bioremediation is not a very useful technology for very heavy oils, such as that from the Erika [30], since only a small fraction of the oil will be biodegraded in a reasonably short timeframe, and thus likely be nitrogen-limited. In this case, only $11 \%$ of the oil was degraded in 80 days. This is enough to cause a microbial bloom [31].

[32] confirmed that spill of several hundred tons of crude oil contaminated a large amount of sand, and 30,000 $\mathrm{m} 2$ were treated with a mixed bacterial culture plus their polymerized fertilizer and tilled twice a week. Overall, the treatment apparently resulted in the degradation of $88 \%$ of the oil after 4 months, during which time there was virtually no change in the oil concentration of a control plot which was tilled in the same way. 
Microorganisms require nitrogen, phosphorus, sulfur, and a number of trace elements. These must be present and in forms that are available to microbial cells. The presence of overly toxic concentrations of heavy metals like mercury, lead, and zinc or of other antimicrobial substances may inhibit or even prevent bioremediation processes [33]. One approach often considered for the bioremediation of petroleum pollutants after an oil spill is the addition of microorganisms (seeding) that are able to degrade hydrocarbons. Most microorganisms considered for seeding are obtained by enrichment cultures from previously contaminated sites. However, because hydrocarbon-degrading bacteria and fungi are widely distributed in marine, freshwater and soil habitats, adding seed cultures has proven less promising for treating oil spills than adding fertilizers and ensuring adequate aeration. Most tests have indicated that seed cultures are likely to be of little benefit over the naturally occurring microorganisms at a contaminated site for the biodegradation of the bulk of petroleum contaminants [11].

[34] reported that the numbers of Dehalococcoides in sludge samples are greatly elevated in places were a contaminated groundwater plume reaches surface waters. This may greatly influence the way to deal with groundwater plumes of chlorinated solvents, when such a natural sludge barrier is available. According to [14] which reported that the first well-publicized use of added bacteria was on the 1990 spill from the Mega Borg in the Gulf of Mexico [35], and more recent use of added bacteria has been on the 1997 spill of Medium Fuel Oil from the Nakhodka in the Sea of Japan [36].

\section{Fungal Mediated Remediation}

Fungi are the most important eukaryotic microorganisms that have distinguish by their ability in existence in different substrates and can use wide range natural and industrial media for growth and reproduction due to possessing a multi enzyme systems that support the fungi to use the more complex materials such as hydrocarbons as a source of carbon needed to fungal metabolism to produce energy as ATP. Although it has more advance eukaryotic physiological structure, fungi developed enzyme systems, form trans-diols, whereas bacteria almost always form cis-diols, many trans-diols are potent carcinogens than cis-diols [11].

In terrestrial environments, fungi can degrade high molecularweight PAHs, and function well [1], clarified that different fungal species are successful at degrading different PAHs and a wide variety of fungi have evolved effective mechanisms to attack specific PAHs due to ability lies in the similarity between lignin, a long, aromatic family of molecules that is present in wood and PAHs.

Clean up oil from different aquatic and terrestrial ecosystems by using mechanical or chemical methods such as booms, and skimmers or burn it, may be with less benefit comparative with save biological treatment process, in addition to fungi in bioremediation is relatively economical as they can be grown on a number of inexpensive agricultural or forest wastes .More so, their utilization is a gentle non-aggressive approach and the application of bioremediation capabilities of indigenous organisms to clean up pollutants is viable and has economic values.

The degradation of hydrocarbons by yeasts and filamentous fungi has been investigated previously and it was concluded that most fungal species are excellent hydrocarbon degraders [37]. reported that the genes responsible for PAH degradation are present as many homologous loci within the genome, which provides a particularly large pool of mutation and rearrangement possibilities within that gene family. found strains of Fusarium and Hypocrea that could degrade one carcinogenic high weight $\mathrm{PAH}$, pyrene, as well as uptake copper and zinc in the soil. These strains were able to use the pyrene as their sole carbon source. The ability of Polyporus sp. S133 collected from petroleum contaminated soil pre-grown on wood meal to degrade crude oil was measured and revealed that the maximal degradation (93\%) was obtained during incubation at $1000 \mathrm{ppm}$ of crude oil for 60 days, and $19 \%$ at $15000 \mathrm{ppm}$ [13].

\section{Bioremediation application of oil spill}

Biodegradation of petroleum products in the marine ecosystems limited by factors of environment such as concentrations of oxygen, phosphate and nitrogen. The rates of petroleum biodegradation are negligible in anaerobic sediments because molecular oxygen is required by most microorganisms for the initial step in hydrocarbon metabolism. Oxygen, however, is not limiting in well aerated (high energy) marine environments [11]. Biodegradation rates mainly depend on the concentration of nitrogen within the shoreline, the oil loading, and the extent to which natural biodegradation had already taken place. The more oil has already degraded, the less likely bioremediation has found to be effective. However, because of the heterogeneity of shorelines and oiling levels, an optimum amount of fertilizer would vary with the location, and the best dosage could not be predicted a priori [38]. Usually, marine waters have very low concentrations of nitrogen, phosphorus and various mineral nutrients that are needed for the incorporation into cellular biomass, and the availability of these within the area of hydrocarbon degradation is critical.

The striking visual results strongly supported the idea that oil degradation in Prince William Sound was nutrient limited and that fertilizer application was a useful bioremediation strategy [11]. Because of its success, Inipol ${ }^{\mathrm{TM}}$ was approved for shoreline treatment and used as a major part of the clean-up effort. After about 2-3 weeks, oil on the surface of cobble shorelines treated with Inipol $^{\mathrm{TM}}$ and Customblen was degraded so that these shorelines were visibly cleaner than non-bioremediated shorelines. Tests demonstrated that fertilizer application sustained higher numbers of oil-degrading microorganisms in oiled shorelines and that rates of biodegradation were enhanced, as evidenced by the chemical changes detected in recovered oil from treated and untreated reference sites [28]. 
Fungi and bacteria both metabolize a wide variety of PAHs, but the principal pathways used by each group are different. The metabolism of PAHs by aerobic bacteria is usually initiated by dioxygenases, which incorporate both atoms of $\mathrm{O} 2$ into the $\mathrm{PAH}$ to form one or more isomeric cis-dihydrodiol metabolites [39]. Bacterial dioxygenases are multicomponent enzyme systems; for instance, naphthalene dioxygenase consists of a ferredoxin reductase, a ferredoxin, and a terminal iron-sulfur protein with large $\alpha$ and small $\beta$ subunits. The cis-dihydrodiols are reduced by dihydrodiol dehydrogenases to form dihydroxylated aromatic intermediates (catechols), which then may serve as substrates for ortho and meta ring-fission dioxygenases [40].

The ring-cleavage products are further metabolized to tricarboxylic acid cycle intermediates and eventually to CO2. In addition, some Streptomyces and Mycobacterium spp. produce monooxygenases that oxidize PAHs to trans-dihydrodiols [37]. The trans-dihydrodiols are encountered much more frequently among the metabolites produced by fungi. Anaerobic biodegradation of PAHs is also known to occur [41].

In the spring of 1989, EPA applied a field studies used bioremediation techniques on oiled shorelines in Prince William Sound. later during 1990, bioremediation process applied in four US spills and during the end of 1990 and the beginning of 1991 bioremediation became more available and with the early of 1992 bioremediation term occupied a satisfied role in biological control methods for oil spill risks treatment. However, the expense and effort required to establish a monitoring program may deter the use of bioremediation at smaller spills [17].

The results of a study interested with the relationship between indigenous and seeded microbial cultures showed, that seeding with local or foreign oil-degrading bacteria did not lead to enhancement of hydrocarbon degradation and resulted in dramatic decreases in the numbers of the predominant, indigenous, oil-degrading bacteria. Whereas local microorganisms were able to As a result of the EPA-Exxon and joint monitoring projects, bioremediation of beach oil was shown to be a safe cleanup process. The addition of fertilizers caused no eutrophication, no acute toxicity to sensitive marine test species, and did not cause the release of undegraded oil residues from the beaches [28].

Besides mechanical recovery, four different bioremediation products have been applied to the beaches. They only lead to limited and inconclusive results. Some changes in oil content were found in the experiments, but it remained unclear, if the removal was physically or biologically mediated [42-44].

\section{References}

1. Fernández-Luqueño F, Valenzuela Encinas C, Marsch R, MartínezSuárez C, Vázquez-Núñez E (2011) Microbial communities to mitigate contamination of PAHs in soil-possibilities and challenges: a review. Environ Sci Pollut Res Int 18(1): 12-30.

2. Mancera-López ME, Rodríguez-Casasola MTA, Ríos Leal AE, Esparza García AF, Chávez Gómez AB, Rodríguez-VázquezBR, et al. (2007) Fungi and Bacteria Isolated from Two Highly Polluted Soils for Hydrocarbon Degradation. Acta Chim Slov 201-209.
3. Pereira JL, Noronha EF, Miller RN, Franco OL (2007) Novel insights in the use of hydrolytic enzymes secreted by fungi with biotechnological potential. Lett Appl Microbiol 44 (6): 573-581.

4. Obire 0 (1988) Studies on the biodegradation potentials of some microorganisms isolated from water systems of two petroleum producing areas in Nigeria. Nigerian Journal of Botany 1: 81-90.

5. American Petroleum Institute (1999) Fate of Oil in Marine Water. Washington, DC, USA, 28-30.

6. Nelson-Smith A (1973) Oil Pollution and Marine Ecology, New York, Plenum Press.

7. Robbins WK, Hsu CS (1996) Petroleum Composition. In Kirk-Othmer Encyclopedia of Chemical Technology, $4^{\text {th }}$ edn. JI Kroschwitz (ed.). New York: Wiley, pp. 352-370.

8. Tissot BP, Welte DH (1984) Petroleum Formation and Occurrence. Berlin: Springer-Verlag.

9. Kim S, Stanford LA, Rodgers RP, Marshall AG, Walters CC, et al. (2005) Microbial alteration of the acidic and neutral polar NSO compounds revealed by Fourier transform ion cyclotron resonance mass spectrometry. Organic Geochemistry 36(8): 1117-1134.

10. Hughey CA, Galasso SA, Zumberge JE (2007) Detailed compositional comparison of acidic NSO compounds in biodegraded reservoir and surface crude oils by negative ion electrospray Fourier transform ion cyclotron resonance mass spectrometry. Fuel 86(5-6): 758-768.

11. Atlas RM (1995) Petroleum biodegradation and Oil Spill bioremediation. Marine Pollution Bulletin 31(4 -12): 178-182.

12. Dibble JT, R Bartha (1979) The effect of environmental parameters on the biodegradation of oily sludge. Appl Environ Microbiol 37(4): 729739.

13. Haiibarata T, Sanro Tachibana (2009) Microbial Degradation of Crude Oil by Fungi Pre-Grown on Wood Meal. In: Y Obayashi, T Isobe, et al. (Eds.), Interdisciplinary Studies on Environmental Chemistry - Environmental Research in Asia, Asia Pp. 317-322.

14. Prince, RC (2012) Bioremediation of marine oil spills. Bioremediation and life science, Hand book of hydrocarbons and lipid microbiology. Springer, online publishers. Iraqi Virtual scientific library.

15. Westlake DW, Jobson A, Phillippe R, Cook FD (1974) Biodegradability and crude oil composition. Can J Microbiol 20(7): 915-928.

16. Atlas RM, Bartha R (1972) Degradation and mineralization of petroleum by two bacteria isolated from coastal water. Biotechnol Bioeng 14(3): 297-308.

17. Hoff, Rebecca Z (1993) Bioremediation: an overview of its development and use for oil spill cleanup. Marine Pollution Bulletin 26(9): 476-481.

18. Atlas, Ronald M (1995) Petroleum Biodegradation and Oil Spill Bioremediation. Marine Pollution Bulletin 31(4-12): 178-182.

19. Díez S, Sabaté J, Viñas M, Bayona JM, Solanas AM, et al. (2005) The prestige oil spill. I. Biodegradation of a heavy fuel oil under simulated conditions. Environ Toxicol Chem 24(9): 2203-2317.

20. Venosa AD, Suidan MT, Wrenn BA, Strohmeier KL, Haines JR, et al. (1996) Bioremediation of an experimental oil spill on the shoreline of Delaware Bay. Environ Sci Technol 30(5): 1764-1775.

21. Wrenn BA, Sarnecki KL, Kohar ES, Lee K, Venosa AD (2006) Effects of nutrient source and supply on crude oil biodegradation in continuous-flow beach microcosms. J Environ Eng 132(1): 75-84.

22. Kanaly RA, Harayama S (2000) Biodegradation of high-molecular-weight polycyclic aromatic hydrocarbons by bacteria. J Bacteriol 182(8): 2059-2067.

23. Kasai Y, Kishira H, Harayama S (2002) Bacteria belonging to the genus 
Cycloclasticus play a primary role in the degradation of aromatic hydrocarbons released in a marine environment. Appl Environ Microbiol 68(11): 5625-5633.

24. Yakimov MM, Timmis KN, Golyshin PN (2007) Obligate oil-degrading marine bacteria. Curr Opin Biotechnol 18(3): 257-266.

25. Bell TH, Greer CW, Yergeau E (2012) Metagenomics Potential for Bioremediation. Biomedical and Life Sciences, Encyclopedia of Metagenomics. Springer.

26. Zhang J, Chiao C (2002) Novel Approaches for remediation of pesticide pollutants. International Journal Environment and Pollution; 18 (5): 423-433.

27. Balba M, Al Awadhi N, Al Daher R (1998) Bioremediation of oil-contaminated soil: microbiological methods for feasibility assessment and field evaluation. Journal of Microbiological Methods 32(2): 155-164.

28. Hohener P, Hunkeler D, Hess A, Bregnard T, Zeyer J (1998) Methodology for the evaluation of engineered in situ bioremediation: lessons from a case study. Journal of Microbiological Methods; 32(2): 179-192.

29. EPA (1990) Interim Report, Oil Spill Bioremediation Project. US Environmental Protection Agency, Office of Research and Development, Washington.

30. Bazylinski DA, Wirsen CO, Jannasch HW (1989) Microbial utilization of naturally occurring hydrocarbons at the Guaymas Basin hydrothermal vent site. Appl Environ Microbiol 55(11): 2832-2836.

31. Oudot J (2000) Biodégradabilité du fuel de l’Erika/Biodegradability of the Erika fuel oil. C R Acad Sci III 323(11): 945-950.

32. Maruyama A, Ishiwata H, Kitamura K, Sunamura M, Fujita T, et al (2003) Dynamics of microbial populations and strong selection for Cycloclasticus pugetii following the Nakhodka oil spill. Microb Ecol 46(4): 442-453.

33. Rosenberg E, Ron EZ (1998) Non-polluting compositions to degrade hydrocarbons and microorganisms. US Patent 5,780,290.
34. Crawford RL (2012)Bioremediation .Bioremediation and life science, The prokaryotes: 1- Symbiotic association .Springer , online publishers. Iraqi Virtual scientific library.

35. Van Bemmel (2012) Intrinsinc Bioremediation of hydrocarbons. Hand book of hydrocarbons and lipid microbiology. Springer online publishers pp. 4509-4516.

36. Holden C (1990) Gulf slick a free lunch for bacteria. Science 249(4965): 120.

37. Tsutsumi H, Kono M, Takai K, Manabe T (2000) Bioremediation on the shore after an oil spill from the Nakhodka in the Sea of Japan. III. Field test of a bioremediation agent with microbiological cultures for the treatment of an oil spill. Marine Pollution Bulletin 40(4): 320-324.

38. Sutherland JB, Freeman JP, Selby AL, Fu PP, Miller DW, et al. (1990) Stereoselective formation of a K-region dihydrodiol from phenanthrene by Streptomyces flavovirens. Archives of Microbiology 154(3): 260-266.

39. Bragg James R, Prince Roger C, Harner E, James Atlas, Ronald M (1994) Effectiveness of bioremediation for the Exxon Valdez oil spill. Nature 368: 413-418.

40. Cerniglia CE (1993) Biodegradation of polycyclic aromatic hydrocarbons. Curr Opin Biotechnol 4: 331-338.

41. Habe H, Omori T (2003) Genetics of polycyclic aromatic hydrocarbon metabolism in diverse aerobic bacteria. Biosci Biotechnol Biochem 67(2): 225-243.

42. Chang BV, Shiung LC, Yuan SY (2002) Anaerobic biodegradation of polycyclic aromatic hydrocarbon in soil. Chemosphere 48(7): 717-724.

43. Swannell Richard PJ, Lee K, McDonagh M (1996) Field Evaluations of Marine Oil Spill Bioremediation. Microbiol Rev 60(2): 342-365.

44. Rosenberg E (1991) Hydrocarbon-oxidizing bacteria. A Balows, H G Truper, et al. (Eds) The Prokaryotes, $2^{\text {nd }}$ (edn) Springer-Verlag New York, NY 446-459.

\section{Your next submission with Juniper Publishers} will reach you the below assets

- Quality Editorial service

- Swift Peer Review

- Reprints availability

- E-prints Service

- Manuscript Podcast for convenient understanding

- Global attainment for your research

- Manuscript accessibility in different formats

( Pdf, E-pub, Full Text, Audio)

- Unceasing customer service

\section{Track the below URL for one-step submission}

https://juniperpublishers.com/online-submission.php 